nature

Volume 252

December 20/27, 1974

\section{Be bold, Mr Varley}

MR Eric Varley took over as Britain's Secretary of State for Energy in an almost new government department nine months ago. He had much goodwill behind him as he struggled to absorb the complexities of the nuclear reactor issues and to negotiate the political and industrial minefield of establishing the government's role in the exploitation of North Sea oil. His decisions on these thorny subjects have been tolerably well received. Alas, while he was coping with the issues of energy in the middle distance, his mind seems to have wandered from the ghastly problems of energy for the present. As a result it has taken nine months for anything of substance to emerge from the Department of Energy on the saving of fuel, and more particularly oil. And what has emerged is modest in the extreme:

- Oil price increases to bear more on the motorist: an extra $8 \mathrm{p}$ on a gallon is expected soon.

- Speed limits on roads other than motorways to be reduced.

- Buildings (other than homes) to be maintained at not more than $20^{\circ} \mathrm{C}$.

- Improvements in thermal insulation standards for new houses.

- Loans to industry for energy-saving investment-up to a national total of $£ 3$ million a year.

None of this is likely to strike terror in the hearts of oil producers. Mr Varley eventually hopes to cut energy consumption by $10 \%$ but first estimates are that this package will save only $2 \%$. Drivers on Britain's quaint single carriageway roads would be hard pressed to find stretches where they could exceed the new speed limit of 50 miles an hour. So we must assume that there are other more significant ideas in the pipeline.

The regrettable thing is that it has taken so long to get this short distance. Mr Varley has been gathering around him an Advisory Council on Energy Conservation -a surprisingly lengthy process considering the urgency of the problem-and he has had the benefit of the Think Tank's gratuitous advice this last summer. Yet the measures proposed could have been put together on the back of an envelope the day he arrived in his new office. What is more, nine months ago the mood of the nation was such that tough measures, already imposed in some cases last winter, would have been acceptable as long term propositions. Psychologically, Britain was prepared to live with some austerity. But such constraints as there had been were lifted, presumably for supposed political gain, and by midsummer the man-in-the-street's perception of the energy crisis was that a saving was no longer necessary. Not only the man-in-the-street. A high ranking civil servant in the Department of Energy admitted that the only permanent change in his behaviour as a result of last winter's crisis was that he now turned the light off in his railway compartment when he got off the train. It is doubtful whether the new measures, which are clearly meant to have as much of a psychological as a physical impact, will restore the lost desire to conserve. What is more, there is almost nothing in Mr Varley's package to encourage industry, the big consumer, to economise.

What is needed is some full blooded government intervention. Whether it takes the form of rationing (and surely the Think Tank could with profit be set to develop a fairly sophisticated scheme for discouraging waste) a massive publicity campaign, jawboning of industrial chiefs or substantial price rises, there are ample opportunities for the government to move fairly deeply into the conservation business. To take one example, such propaganda as the government and nationalised industries have produced so far has seemed unbelievably halfhearted. Discreet advertisements in newspapers will persuade nobody. An enormous effort to raise national consciousness is called for, and this will need a large budget and much imagination. As a result of it, the general public might even end up appreciating solutions of the thermal diffusion equation-more than many scientists do at present. And perhaps someone will develop cheap continuously recording thermometers and other cost-monitoring devices.

Ultimately, the government will have to face up to the central message of the energy crisis-that our way of life will have to change if Britain is to remain solvent. The same is true, of course, of all other countries similarly afflicted, but Britain will be the first to suffer if radical measures are not taken soon. It is strange that an external military threat would be perceived immediately and the public called upon to make sacrifices, whereas an economic threat is deemed unsuitable material with which to go to the country and ask for belt-tightening. Mr Varley might be pleasantly surprised by the response if he chanced his arm considerably more.

\section{A hundred years ago}

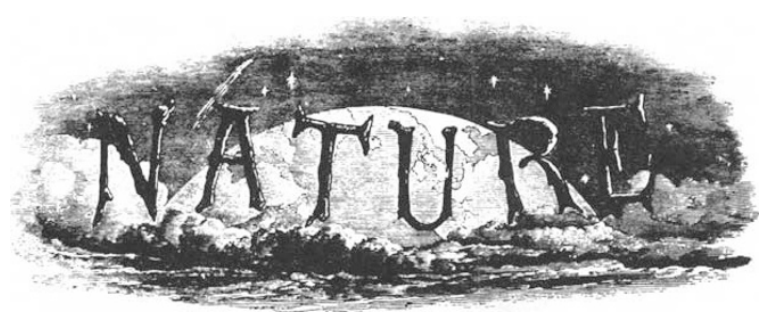

THE process of polishing the lens of the mirror of the great telescope is going on at the French National Observatory by M. Martin. The diameter of the lens is $x 20$ centimetres, and the polisher is a disc of 40 centimetres. The number of men engaged on the polishing is six. They are obliged to stop frequently on account of the great weight of the polisher. An observer placed on the top of the Observatory, at a distance equal to half the focal distance, superintends the polishing process, watching if the image of a light which is placed in a proper position is reflected with sufficient exactness by the mirror below.

From Nature, 11, 154, December 24, 1874. 